\title{
Rhabdomyolysis in Indonesian marathon athlete
}

\author{
Riadi Wirawan, Marina Ludong
}

\begin{abstract}
Abstrak
Telah dilakukan pemeriksaan kadar mioglobin serum \& urin pada 37 atlet maraton nasional peserta pertandingan Asian Marathon III \& Proklamaton XV. Tiga atlet menunjukkan kadar mioglobin < 50 ug/L dan 34 atlet yang lain menunjukkan kadar mioglobin 211 $3300 \mathrm{ug} / \mathrm{L}$. Rhabdomiolisis didapatkan hanya pada 2 atlet sehingga angka kejadian rhabdomiolisis adalah 6,1\%. Didapatkan korelasi bermakna antara mioglobinemia dan prestasi lari. (Med J Indones 2003; 12: 207-14)
\end{abstract}

\begin{abstract}
Serum and urine myoglobin assessments were conducted on 37 national marathon athletes who participated in the Asian Marathon III \& Proklamaton XV. Three athletes showed a myoglobin value of $<50 \mathrm{ug} / \mathrm{L}$ and the other 34 athletes showed a myoglobin value of 211-3300 ug/L. Rhabdomyolysis were only found in 2 athletes, thus the prevalence of rhabdomyolysis is $6.1 \%$. A correlation was found between myoglobinemia value and the athlete's performance. (Med J Indones 2003; 12: 207-14)
\end{abstract}

Keywords: Rhabdomyolysis, myoglobinemia \& myoglobinuria

Heavy exercises such as marathon can cause muscular damage, known as rhabdomyolysis. In this case, the myoglobin is released from muscle cells and enters the blood circulation, termed as myoglobinemia. After filtration in the glomerulus, half of the myoglobin is reabsorbed by the renal tubule, while the remaining half is excreted into the urine as myoglobinuria. The high concentration of myoglobin in the urine changes the color of urine to brownish-red. ${ }^{1,2}$ The concentration of myoglobin in serum recovers to normal level within 24 hours. $^{3}$

Myoglobin is an iron containing pigment similar to hemoglobin and is found in skeletal and cardiac muscles. It binds one oxygen molecule. Myoglobin takes the oxygen from hemoglobin and releases it when the pressure of oxygen is low. In the contracting muscle, the pressure of oxygen is almost zero; therefore myoglobin is mostly present in the contracting muscle. On muscle contraction, the blood flow decreased, resulting in the decrease of oxygen

Department of Clinical Pathology, Faculty of Medicine University of Indonesia/ Dr. Cipto Mangunkusumo General Hospital, Jakarta, Indonesia supply to the muscle. In this condition, the oxygen demand is supplied by myoglobin. It is known that the myoglobin facilitates the diffusion of oxygen from blood cell into the mitochondria of muscle cells in order to produce ATP as the source of energy through oxidative reaction in the mitochondria. ${ }^{4,5}$

In addition heavy exercises may cause changes in many organs of the body, such as heart, intestine, skin, kidney, urinary tract, and muscle. One of those is hematuria, also known as sports hematuria. ${ }^{6}$ In urinalysis, except hematuria, there are also hemoglobinuria, proteinuria, cast, and increased leucocytes count. This symptom is called athlete pseudonephritis. ${ }^{7}$ Intraluminal plaques of myoglobin in the renal tubule accompanied by hypoperfusion are the source of acute tubular necrosis that can cause renal failure in the end. ${ }^{1,2}$

In marathon, the athlete attempts to achieve the best result, so that hypoxia of tissues can occur rapidly followed by muscle damage that causes myoglobinemia and myoglobinuria. Since the myoglobin contains iron, this condition can induce renal excretion of iron. ${ }^{8}$

Frequent excretion of myoglobin through the kidney in the long run, not only cause renal dysfunction, but may also cause iron deficiency and finally influences 
the synthesis of hemoglobin, myoglobin and respiratory enzymes. ${ }^{8,9}$ When all of these occur, the physical condition and performance of the athlete becomes worse. However, the interests of many researchers in rhabdomyolysis in correlation to the increasing performance of the athletes are still poor.

The aims of this research were to investigate the incidence of rhabdomyolysis in the national marathon athletes after the race, and to evaluate the correlation between the blood myoglobin level and the performance of athletes. Since myoglobin might cause renal dysfunction, we also investigated the possible correlation between the increase in myoglobin level and creatinine level.

\section{METHODS}

\section{Collecting of samples}

Thirty-seven national marathon athletes who participated in the Asian Marathon Event III and Proklamaton $\mathrm{XV}$ were recruited for this research. Thirty $\mathrm{ml}$ of urine from each athlete was collected before the race (urine myoglobin I), followed by collecting $30 \mathrm{ml}$ of urine (urine myoglobin II) and 4 $\mathrm{ml}$ of blood two hours after the race for serum myoglobin and creatinine level assessments.

\section{Methods}

Preliminary test

Within day and between day precision and accuracy test were done by serum myoglobin control using turbitimer from Dade Behring.

\section{Serum myoglobin measurement}

Serum myoglobin was measured based on immunochemical reaction. In this reaction the polystyrene particles covered by human myoglobin antibody would undergo agglutination with myoglobin containing serum, thus the solution become turbid. The turbidity level of the solution was then measured photometrically by using turbitimer from Dade Behring.

Fifty $\mu \mathrm{l}$ of serum was pipetted into a cuvette. Subsequently the cuvette was inserted into the defined site of turbitimer. Five hundred $\mu \mathrm{l}$ of reagent was then pipetted into the cuvette. The presence of myoglobin in the solution was automatically calculated by turbitimer. $^{3}$

\section{Myoglobinuria test}

Myoglobinuria test was based on the difference in saturation level of ammonium sulfate used to precipitate hemoglobin and myoglobin in the urine. Filtration test was performed to detect the presence of myoglobin or hemoglobin by adding $3 \mathrm{ml}$ of $3 \%$ sulfosalicylate solution into $1 \mathrm{ml}$ of urine. After mixing, the presence of colored precipitate that indicates the positive result was then observed. If the result was positive, the subsequent test should be done. ${ }^{5}$

In the subsequent test $2.8 \mathrm{~g}$ of ammonium sulfate was added into $5 \mathrm{ml}$ of urine. After mixing, the solution was then filtrated or centrifuged at $2500 \mathrm{rpm}$ for 10 minutes. The red or blackish-brown color on the filtrated solution or supernatant indicates the presence of myoglobin. Then $0.8 \mathrm{~g}$ ammonium sulfate was added into the supernatant. If the color of supernatant became clear, it indicates positive myoglobin reaction. ${ }^{5}$

\section{Creatinine assay}

Serum creatinine was assayed according to Jaffe reaction using the automatic chemistry analyzer from Hitachi 737.

\section{Analysis of data}

Data was collected in a general table. Data were analyzed by calculating the frequency distribution of myoglobinemia and myoglobinuria. Correlation between myoglobinemia and the athlete's performance were analyzed by using Pearson's $r$ product moment correlation method. Correlation between myoglobinemia and serum creatinine was analyzed by a Pearson's $r$ product moment correlation.

\section{RESULTS}

Within day precision and accuracy tests for serum myoglobin assessments were done by using serum myoglobin control and were repeated 5 times consecutively, with the result of coefficient of variation (CV) of $3.7 \%$ and deviation (D) of $6.6 \%$ (Table 1). Between day precision test were done 5 days consecutively using the same controls and showed a CV of $3.9 \%$ and a deviation (D) of $6.8 \%$.

The total numbers of national marathon athletes examined for this experiment were 34 athletes (32 men and 2 women). All of them exhibited an increase in serum myoglobin level after the race (Table 2). 
Table 1. Within day and between day precision test using the serum myoglobin control from Behring

\begin{tabular}{ccc}
\hline No. & $\begin{array}{c}\text { Precision } \\
\text { within day } \\
(\mu \mathrm{g} / \mathrm{L})\end{array}$ & $\begin{array}{c}\text { Precision } \\
\text { between day } \\
(\mu \mathrm{g} / \mathrm{L})\end{array}$ \\
\hline 1 & 90.9 & 96.7 \\
2 & 95.8 & 96.4 \\
3 & 95.3 & 100 \\
4 & 100 & 92.8 \\
5 & 98.9 & 90.8 \\
\hline $\mathrm{X}$ & 96.18 & 95.97 \\
$\mathrm{SD}$ & 3.56 & 3.82 \\
$\mathrm{CV}$ & $3.7 \%$ & $3.9 \%$ \\
$\mathrm{D}$ & $6.6 \%$ & $6.8 \%$ \\
\hline
\end{tabular}

Table 2. Myoglobinuria, serum myoglobin, serum creatinine and running achivement

\begin{tabular}{|c|c|c|c|c|c|}
\hline No. & $\begin{array}{c}\text { urine } \\
\text { myoglobin I }\end{array}$ & $\begin{array}{c}\text { urine } \\
\text { myoglobin II }\end{array}$ & $\begin{array}{c}\text { serum } \\
\text { myoglobin } \\
(\mu \mathrm{g} / \mathrm{L})\end{array}$ & $\begin{array}{l}\text { serum } \\
\text { creatinine } \\
(\mu \mathrm{g} / \mathrm{L})\end{array}$ & $\begin{array}{l}\text { running achivement } \\
\text { (hour, minute } \\
\text { second) }\end{array}$ \\
\hline 1 & - & - & 211 & 1.3 & $2: 26: 03$ \\
\hline 2 & - & + & 213 & 1.2 & $2: 44: 31$ \\
\hline 3 & - & - & 214 & 1.3 & $2: 46: 01$ \\
\hline 4 & - & - & 223 & 0.9 & $2: 54: 24$ \\
\hline 5 & - & - & 226 & 1.2 & $2: 35: 13$ \\
\hline 6 & - & - & 289 & 0.9 & - \\
\hline 7 & - & - & 305 & 1.3 & - \\
\hline 8 & - & - & 359 & 1.2 & $2: 20: 23$ \\
\hline 9 & - & - & 465 & 1.0 & - \\
\hline 10 & - & - & 504 & 0.9 & $2: 35: 38$ \\
\hline 11 & - & - & 504 & 1.1 & $2: 45: 27$ \\
\hline 12 & - & - & 557 & 0.9 & $2: 35: 38$ \\
\hline 13 & - & - & 570 & 0.9 & $2: 46: 54$ \\
\hline 14 & - & - & 665 & 0.9 & $2: 30: 14$ \\
\hline 15 & - & - & 691 & 1.3 & $2: 53: 29$ \\
\hline 16 & - & - & 714 & 1.1 & - \\
\hline 17 & - & - & 752 & 0.9 & $2: 50: 18$ \\
\hline 18 & - & - & 810 & 1.3 & $2: 31: 34$ \\
\hline 19 & - & - & 922 & 0.9 & $3: 22: 19$ \\
\hline 20 & - & - & 957 & 0.9 & $2: 54: 31$ \\
\hline 21 & - & - & 962 & 1.1 & $2: 31: 51$ \\
\hline 22 & - & - & 974 & 1.3 & $2: 48: 03$ \\
\hline 23 & - & - & 1040 & 1.1 & $2: 37: 17$ \\
\hline 24 & - & - & 1130 & 1.0 & $2: 55: 33$ \\
\hline 25 & - & - & 1210 & 1.3 & - \\
\hline 26 & - & - & 1460 & 1.3 & - \\
\hline 27 & - & - & 1490 & 1.1 & - \\
\hline 28 & - & - & 1560 & 0.9 & - \\
\hline 29 & - & - & 1815 & 1.1 & $3: 15: 21$ \\
\hline 30 & - & - & 1872 & 1.2 & $3: 05: 46$ \\
\hline 31 & - & + & 2600 & 0.9 & $3: 11: 04$ \\
\hline 32 & - & - & 2660 & 0.9 & $2: 44: 59$ \\
\hline 33 & - & - & 3130 & 1.1 & - \\
\hline 34 & - & - & 3300 & 1.0 & $2: 57: 50$ \\
\hline
\end{tabular}

Urine I : before running

Urine II : after running

Speed achivement : in hour, minute, second 
The results from 34 athletes were grouped into 5 groups according to serum myoglobin levels i.e. (1) $80-800 \mu \mathrm{g} / \mathrm{L}$ (10 times the normal value); (2) 801$1600 \mu \mathrm{g} / \mathrm{L}$ (20 times the normal value); (3) 1601-2400 $\square \mu \mathrm{g} / \mathrm{L}$ (30 times the normal value); (4) $2401-3200$ $\mu \mathrm{g} / \mathrm{L}$ (40 times the normal value); and (5) 3201-4000 $\square \mu \mathrm{g} / \mathrm{L}$ (50 times the normal value). The frequency distributions were then observed (Fig.1).

The results showed that $50 \%$ of athletes had serum myoglobin level between $80-800 \mu \mathrm{g} / \mathrm{L}$. The remaining $32.4 \% ; 5.9 \%$; $8.8 \%$; and $2.9 \%$ of athletes had serum myoglobin level between 801-1600 $\mu \mathrm{g} / \mathrm{L} ; 1601-2400$ $\square \mu \mathrm{g} / \mathrm{L} ; 2401-3200 \square \mu \mathrm{g} / \mathrm{L}$ and 3201-4000 $\square \mu \mathrm{g} / \mathrm{L}$, respectively (Fig.2).

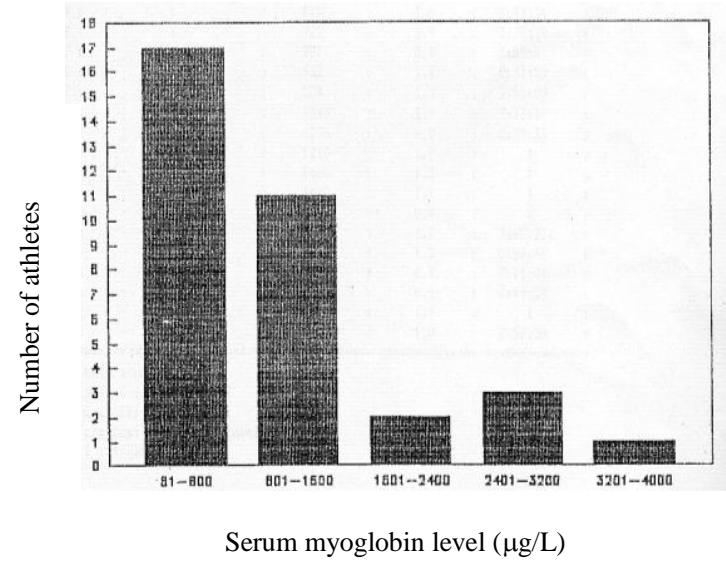

Figure 1. Number of athletes and serum myoglobin level $(\mu g / L)$

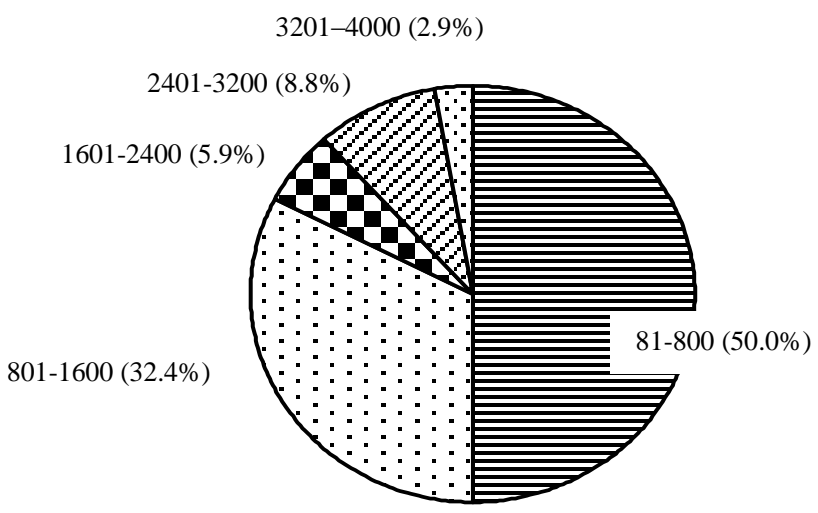

Figure 2. Myoglobinemia in the marathon athletes after running

Myoglobinuria was not found in the pre-running urine examination and it was found only in 2 athletes after running, representing the incidence of myoglobinuria of about $6.1 \%$ (Fig.3).

Figure 4 showed the correlation between myoglobinemia and marathon athletes' performance in the form of a linear line $\mathrm{Y}=0.01 \mathrm{X}+157.1$, with $\mathrm{r}=0.55$ and $\mathrm{t}=3.08$.

Figure 5 showed the correlation between myoglobinemia and serum creatinine in the form of a linear line $\mathrm{Y}=1.12-0.001 \mathrm{X}$ with $\mathrm{r}=-0.11$ and $\mathrm{t}=$ 0.63 . 


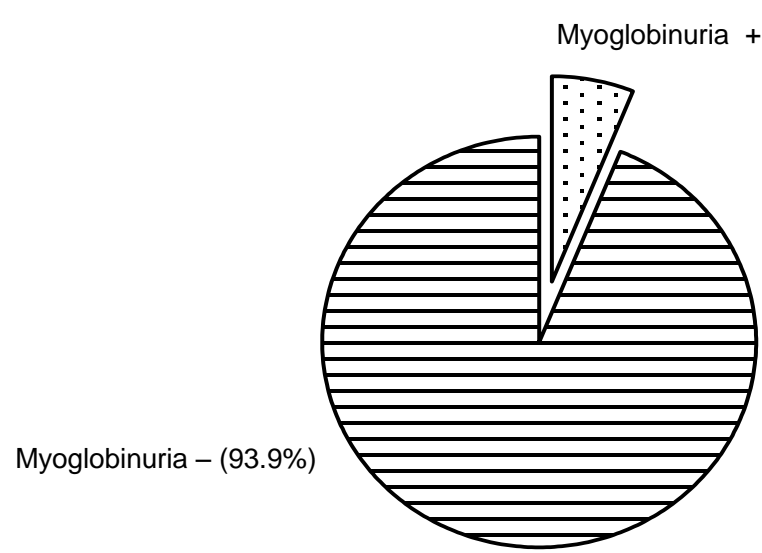

Figure 3. Myoglobinuria in the marathon athletes after running

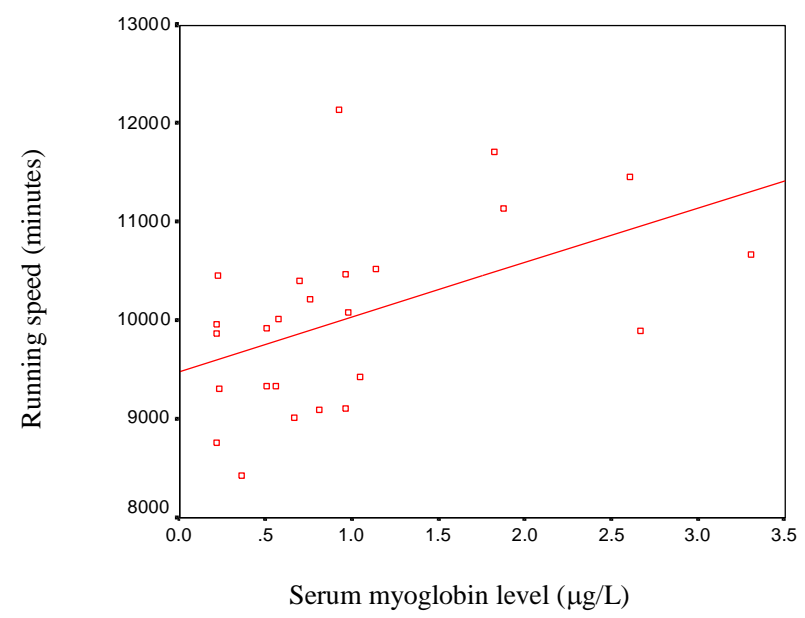

Figure 4. Correlation between myoglobinemia and athlete's performance

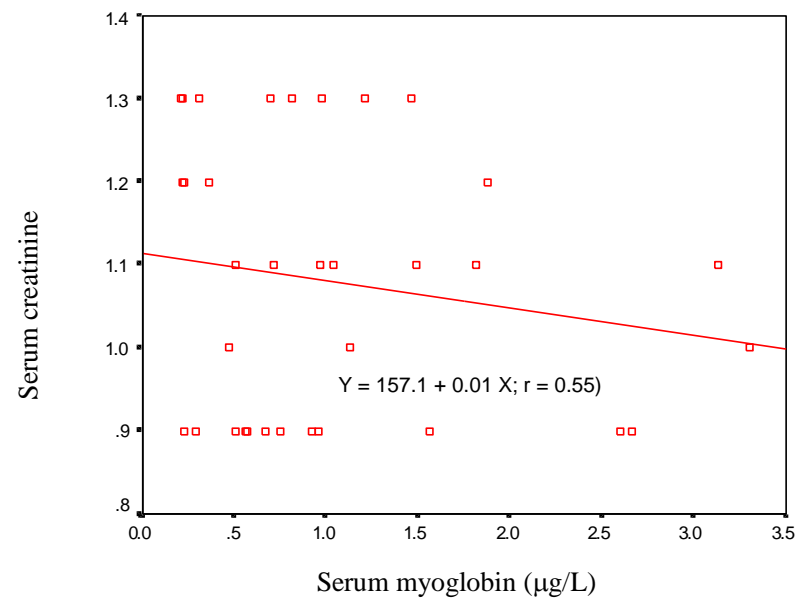

Figure 5. Correlation between myoglobin and creatinine serum 


\section{DISCUSSION}

Marathon is an aerobic sport that needs a prime physical endurance. Marathon athletes should run along a distance of $42 \mathrm{~km}$ (26.2 miles) within the shortest time, in which those athletes should have the capacity to maintain muscle activity for several hours. To maintain the activity of muscle for a long time, a large amount of energy is required continuously. The requirement for energy is provided by ATP hydrolysis, originated from the hydrolysis of glycogen, glucose, and lipid in an aerobic manner. ${ }^{10}$

The ATP production from aerobic metabolism is influenced by the amount of oxygen in the muscle cell and its capacity to use the oxygen. It was known that muscle oxygenation is highly correlated with myoglobin. ${ }^{4}$

As explained previously, in severe exercises such as marathon, rhabdomyolysis can occur, cause the release of myoglobin from muscle cells that enters the blood circulation. This condition decreases the oxygenation in the muscle and the consequence is that energy decreases.

The serum myoglobin level differs according to age and gender. In normal condition, the serum myoglobin level in a man is less than $80 \square \mu \mathrm{g} / \mathrm{L}$ and in a woman less than $60 \square \mu \mathrm{g} / \mathrm{L}$. In children, serum myoglobin level is lower compared to that of an adult. ${ }^{5}$

Myoglobinuria and hemoglobinuria are difficult to distinguish between by visual method, because both of them gave a brown-red color. In addition, the chemical tests for both proteins give positive result as well as occult blood test. The common method used to differentiate them is the precipitation method by ammonium sulfate. ${ }^{11}$

The serum myoglobin level can be measured by performing the assay based on immunochemical reaction such as immunoprecipitation. ${ }^{3,12}$ In this research the myoglobin in the serum was tested according to the principles of immunochemical reaction by using the reagent of Turbiquant Myoglobin and was read with turbitimer analyzer.

Before assessment, the within day and between day precision and accuracy test were done using serum myoglobin control from Dade Behring. The result was good, because the value of CV was less than the suggested value for that test. The suggested value of
CV for within day and between day were 6.8 and 7\%, respectively. ${ }^{3}$ The results of both within day and between day precision test showed a good precision.

From 37 Indonesian national athletes listed for Asian Marathon III and Proklamaton XV in Bandung, 3 athletes failed to participate. However, we still examined their serum myoglobin level. The serum myoglobin level from those 3 athletes could not be measured because their values were less than $50 \square \mu \mathrm{g} / \mathrm{L}$. This information could explain that the myoglobinemia that occurred in the athletes after running was really caused by the heavy work of muscles that caused the muscular injury know as acute exertional rhabdomyolysis. The presence of myoglobin in the serum is a specific indicator for muscle injury because myoglobin is only present in the cardiac and skeletal muscle. ${ }^{13}$

Acute exertional rhabdomyolysis that occurred in healthy individuals is caused by severe exercise. This abnormality can occur from light until mild in gradation and is self limited and harmless if detected rapidly and managed adequately. ${ }^{13-15}$

In this research the blood and urine were collected 2 hours after running, since in muscular injury the continuity of sarcolemma was disrupted, implicating in the release of myoglobin immediately from intracell to the blood and the increase of myoglobin in the blood would appear within 2-3 hours. Myoglobin has a molecular weight of 17000 Dalton and can be filtrated by glomerulus, but most of it is reabsorbed in the renal tubule and a little amount is excreted into urine. ${ }^{1,2,16}$

Hackl et al reported that there was no correlation between the increase of myoglobin concentration in the serum and urine. ${ }^{2}$ These results can be read in the experimental reports from Stansbie and Begley in 1978 performed on 44 marathon athletes in the North Africa. From 44 examined athletes, 25 of them exhibited the increase of myoglobin in the serum significantly and from those 25 athletes, only 5 athletes had myoglobinuria and none of them had renal failure. ${ }^{17}$ As shown in this research from 34 athletes examined after running, all of them exhibited increased serum myoglobin level with the average of $967.21 \square \mu \mathrm{g} / \mathrm{L}$, but only 2 athletes showed positive results on urine myoglobin assessment.

If the serum myoglobin level increases, the possibility of myoglobinuria also increases. Consequently, the 
possibility of iron release via urine will also increase. Repeated myoglobinemia and myoglobinuria in the marathon athletes can induce iron deficiency especially in athletes who frequently have hematuria and hemoglobinuria. If this condition is also accompanied with myoglobinuria, the chance for iron deficiency also increases.

Several journals reported that athletes with routine exercises in which the load of exercise was increased gradually with a sufficient warming up showed a slight increase of myoglobin in the serum suggesting that severe rhabdomyolysis could be prevented. ${ }^{11}$

The statistical analysis showed loose correlation between blood myoglobin level and athlete performance $(\mathrm{r}=0.55)$, however the significance test (t) showed that mioglobinemia influenced the performance of athlete. An athlete with myoglobin level below $1000 \mu \mathrm{g} / \mathrm{L}$ had an average time record of 2 hours and 40 minutes, while an athlete with myoglobin level above $1000 \mu \mathrm{g} / \mathrm{L}$ had the average of 3 hours and 3 minutes. We found that 12 athletes had myoglobin level above $1000 \mu \mathrm{g} / \mathrm{L}$ and 5 of them failed to reach the finish line.

Hackl et al their investigation reported that there was no correlation between the increase of myoglobin level and creatinine clearance. ${ }^{2}$ Some journals reported that repeated myoglobinuria during severe exercise, accompanied by other conditions aggravating renal perfusion such as acidosis, hypotension, and dehydration could facilitate renal dysfunction. ${ }^{8,18}$ In this research there was no correlation between the increase of serum myoglobin and creatinine level.

The pathogenesis of acute tubular necrosis is due to the deposit of myoglobin in the renal tubuli followed by renal hypoperfusion and disturbance of endogenous mediator in cell function. It could be observed that myoglobinemia and myoglobinuria without any other abnormality such as severe dehydration, acidosis, etc could not cause acute tubular necrosis.

\section{CONCLUSION}

In this research, myoglobin assessment was done on serum and urine from 37 national marathon athletes who participated in the Asian Marathon Event III and Proklamaton XV. Three of them failed to participate in those events and the myoglobin level in their serum could not be detected because the value was less than $50 \mu \mathrm{g} / \mathrm{L}$. The other 34 athletes exhibited a significant increase in serum myoglobin level after running. There were only 2 athletes that showed positive myoglobinuria representing the incidence of rhabdomyolysis of about $6.1 \%$. The correlation between myoglobinemia and athlete performance was not strong, but the significance test indicated that myoglobinemia influenced athlete performance. The athletes with increased serum myoglobin level of above $1000 \mu \mathrm{g} / \mathrm{L}$ performed less well compared to those with myoglobin level below $1000 \mu \mathrm{g} / \mathrm{L}$. There was no correlation between serum myoglobin and creatinine level after running.

\section{SUGGESTION}

Since rhabdomyolyisis characterized by myoglobinemia and myoglobinuria can occur in the athletes undergoing severe exercises such as marathon, it is suggested that the athletes should not have the tendency of getting hypoxia as the result of several conditions such as hemoglobinopathy, which could worsen their condition and performances. Therefore it is better to do the screening tests in advance for someone who wants to become an athlete to avoid the conditions explained above.

\section{REFERENCES}

1. Greenberg J, Arneson L. Exertional rhabdomyolysis with myoglobinuria in a large group of military trainees Neurology, 1967; 17: 216 - 22.

2. Hackl JM, Neumann M, Weirather E, Strochneider E. Myoglobin release and renal function in polytraumatized patients in intensive care. Anaesthesist, 1990, 39(6) : 319-22.

3. Anonim. Turbiquant myoglobin reagents. Behring diagnostic, November 1991. Marburg, Germany.

4. Ganong WF. Myoglobin. In : Ganong WF. Review of Medical Physiology. $9^{\text {th }}$ ed. California : Lange Medical publication, 1979: $494-500$.

5. Fairbanks VF, Klee GG. Myoglobin. In : Tietz NW. (ed) Textbook of Clinical chemistry $9^{\text {th }}$ ed. Philadelphia: W. B. Saunders, 1986: $1562-4$.

6. Abarbanel J, Benet AE, Lask D, Kimche D. Sports hematuria. J Urol, 1990, 143(5) : 887 - 90.

7. Milne CJ. Rhabdomyolysis, myoglobinuria and exercise. Sports Med, 1988, 6(2) : 93 - 106.

8. Paller S. Hemoglobin and myoglobin-induced acute renal failure: Role of Iron in Nephrotoxicity. Am Physiol Society, 1988 F : $539-43$.

9. Feinstein EL, Akmal Moh., Telfer N, Massry SG. Delayed hyperglycemia with acute renal failure associated with 
nontraumatic rhabdomyolysis. Arch Intern Med, 1981; 141: $753-5$.

10. Lamb DR. Energi Metabolism. In: Lamb DR, ed. Physiology of Exercise: Responses and Adaptation. $2^{\text {nd }}$ ed. London: Collier Mac Millan, 1984: 38 - 62.

11. Beutler E. Differentiation of hemoglobin and myoglobin in urine. In: William WJ, Beutler E, Erslev AJ, Lichtman MA. (ed). Hematology. $4^{\text {th }}$ ed. International edition, New York: McGraw-Hill, 1991: 1731 - 2 .

12. Perkoff GT, Hill RL, Brown DM, Tyler FH. The Characterization of adult human myoglobin. J Biol Chem, 1962; 237(9): $2820-7$.

13. Olerud JE, Homer LD, Carroll HW. Incidence of acute exertional rhabdomyolysis. Arch Intern Med, 1976; 136: $692-7$.
14. Demos MA, Gitin EL, Kagen LJ. Exercise myoglobinemia and acute exertional rhabdomyolisis. Arch Intern Med, 1974; 134: $669-73$.

15. Turell DJ. Primary myoglobinuria and exercise induced secondary myoglobinuria; A report of 7 cases seen at an army basic training center. South Med J, 1961; 54: $442-8$.

16. Standsbie D, Begley JP. Biochemical consequences of exercise. JIFCC, 1991; 3(2): 87 - 90

17. Ward MM. Factors predictive of acute renal failure in rhabdomyolysis. Arch Intern Med, 1988; 148: 1553-7.

18. Olerud JE, Homer LD, Carroll HW. Serum myoglobin levels predicted from serum enzym values. The New England Journal of Medicine, 1975; 293(10): 483 - 5. 